\title{
Paracoccus halophilus sp. nov., isolated from marine sediment of the South China Sea, China, and emended description of genus Paracoccus Davis 1969
}

\author{
Zhi-Pei Liu, Bao-Jun Wang, Xing-Yu Liu, Xin Dai, Ying-Hao Liu \\ and Shuang-Jiang Liu
}

Correspondence Shuang-Jiang Liu liusj@sun.im.ac.cn

\author{
State Key Laboratory of Microbial Resources, Institute of Microbiology, Chinese Academy of \\ Sciences, Beijing 100080, PR China
}

The genus Paracoccus was first described by Davis et al. (1969) and the description was emended by Katayama et al. (1995). At the time of writing, the genus comprises 22 recognized species names (see Fig. 1, below). Representatives of Paracoccus are able to grow heterotrophically on a wide range of organic compounds. A number of Paracoccus species can also grow chemoautotrophically and use nitrate as electron acceptor (such as Paracoccus denitrificans, Ludwig et al., 1993), or use hydrogen as electron donor (such as Paracoccus versutus, Katayama et al., 1995). Members of the genus Paracoccus are metabolically versatile and are widely distributed in soil (Siller et al., 1996; Tsubokura et al., 1999), bioreactors (La et al., 2005; Lipski et al., 1998), activated sludge (Katayama et al., 1995; Liu et al., 2006) and in the marine environment (Pukall et al., 2003; Berry et al., 2003; Lee et al., 2004; Kim

The GenBank/EMBL/DDBJ accession number for the $16 \mathrm{~S}$ rRNA gene sequence of strain $\mathrm{HN}-182^{\top}$ is $\mathrm{DQ} 423482$.

An electron micrograph of strain $\mathrm{HN}-182^{\top}$ and a figure showing its polar lipids profile are available as supplementary material with the online version of this paper. et al., 2006). In this study, a marine bacterial isolate, the strain $\mathrm{HN}-182^{\mathrm{T}}$ that is able to grow at $7{ }^{\circ} \mathrm{C}$ and high salt concentrations $(8 \% \mathrm{NaCl})$, was investigated for its taxonomic status. Based on phenotypic and genotypic studies it is concluded that this marine isolate represents a novel species within the genus Paracoccus.

Strain HN-182 ${ }^{\mathrm{T}}$ was isolated from marine sediment (GPS coordinates for the sampling site are $21^{\circ} 18.65^{\prime} \mathrm{N} 115^{\circ}$ $15.90^{\prime} \mathrm{E}$ ) with marine agar 2216 (MA; Difco), during an ecological survey on the bacterial diversity of the South China Sea. Tenfold dilutions of the sample were prepared with sterile saline solution, and $0.1 \mathrm{ml}$ of each dilution was spread out on MA plates (pH 7.0). The plates were incubated at $30{ }^{\circ} \mathrm{C}$ for 2 days. Strain $\mathrm{HN}-182^{\mathrm{T}}$ was obtained after several streakings and transfers on MA plates.

Routine cultivation was conducted at $30{ }^{\circ} \mathrm{C}$ with $\mathrm{MA}$ media. Gram reactions were determined by staining cells grown on $\mathrm{MA}$ at $30{ }^{\circ} \mathrm{C}$ for $24 \mathrm{~h}$, according to the method described by Gerhardt et al. (1994). Endospore formation was detected by malachite green staining. Flagellation was 
examined by transmission electron microscope (H-600, Hitachi) after negative staining with $1 \%(\mathrm{w} / \mathrm{v})$ phosphotungstic acid. Morphological observations were carried out using a scanning electron microscope (FEI Quanta 2000). Physiological and biochemical tests, including catalase and oxidase activities, indole production, hydrolysis of starch and nitrate reduction, were carried out according to Dong \& Cai (2001). The $\mathrm{pH}$ range, $\mathrm{NaCl}$ tolerance and the temperature range for growth were determined in marine broth 2216 (MB; Difco). Aerobic and anaerobic production of acids (OF reaction) from carbohydrates was determined in OF basal medium (Hugh \& Leifson, 1953). Carbohydrate solutions sterilized by filtration were added at $1 \%(\mathrm{w} / \mathrm{v})$, and acid production was recorded after 7 and 14 days incubation. For testing growth on reduced sulfur and elemental sulfur, strain $\mathrm{HN}-182^{\mathrm{T}}$ was cultivated for 2 weeks in Allen's medium (Allen, 1959), which was modified by addition of elemental sulfur $(1 \%)$, sulfide $(1 \%)$, thiosulfate $(1 \%)$ or sulfite as energy source and $\mathrm{NaCl}(4.5 \%)$, and the $\mathrm{pH}$ was adjusted to 6.5. Cell growth was estimated by monitoring the increase in turbidity at $600 \mathrm{~nm}$. Cellular fatty acids were extracted from cells grown in MA at $30{ }^{\circ} \mathrm{C}$ for 2 days and subsequently analysed as described previously ( $\mathrm{Hu}$ et al., 2004). Polar lipids were examined by two-dimensional TLC and visualized by spreading reagents specific for $\alpha$ glycols (periodate-Schiff), sugars ( $\alpha$-naphthol $/ \mathrm{H}_{2} \mathrm{SO}_{4}$, anisaldehyde $/ \mathrm{H}_{2} \mathrm{SO}_{4}$ ), free amino groups (ninhydrin) and phosphate (Zindzadze) (Ventosa et al., 1993). A $50 \%$ sulfuric acid solution was used to detect spots of all kinds of lipids (Fujii et al., 2003). Quinones were determined according to Collins (1985) and Wu et al. (1989). DNA base composition was determined by thermal denaturation (Marmur \& Doty, 1962). The 16S rRNA gene was amplified as described previously (Zhang et al., 2003), and $16 \mathrm{~S}$ rRNA gene sequence alignment was performed with the CLUSTAL_X program (version 1.64b; Thompson et al., 1997). A phylogenetic tree (Fig. 1) was constructed by the neighbour-joining method with Kimura's twoparameter calculation model in MEGA version 3.1 (Kumar et al., 2004).

Compared with other Paracoccus species, strain $\mathrm{HN}-182^{\mathrm{T}}$ is characterized by its growth at lower temperature $\left(7{ }^{\circ} \mathrm{C}\right)$ and higher $\mathrm{NaCl}$ concentration $(8 \%, \mathrm{w} / \mathrm{v})$, as well as its ability to utilize D-xylose and some other carbon sources. Strain $\mathrm{HN}-182^{\mathrm{T}}$ was not capable of growing autotrophically on reduced sulfur. More physiological and biochemical properties of strain $\mathrm{HN}-182^{\mathrm{T}}$ are provided in the species description (see below) and comparisons of strain $\mathrm{HN}-182^{\mathrm{T}}$ with other Paracoccus species are listed in Table 1.

Strain $\mathrm{HN}-182^{\mathrm{T}}$ contains ubiquinone-10 (Q-10) as the sole respiratory quinone. Strain $\mathrm{HN}-182^{\mathrm{T}}$ contains five polar lipids (Supplementary Fig. S2, in IJSEM Online): diphosphatidylglycerol (DPG), phosphatidylcholine (PC), phosphatidylglycerol (PG), an unidentified glycolipid (GL1) and an unidentified phospholipid (PL1). Among these, PG, PL1 and GL1 are the major polar lipids. Phosphatidylethanolamine (PE), which is commonly present in Gram-negative bacteria, was not detected in the lipid extracts of strain $\mathrm{HN}-182^{\mathrm{T}}$. Within the Rhodobacteraceae, the absence of PE was also reported for Rubellimicrobium thermophilum (Denner et al., 2006), Antarctobacter heliothermus, Roseobacter denitrificans, Roseobacter litoralis, Roseisalinus antarcticus and Thalassobacter stenotrophicus (Labrenz et al., 1998, 1999, 2005; Macián et al., 2005).The major cellular fatty acids $(>5 \%)$ were $\mathrm{C}_{18: 1} \omega 7 c(60.7 \%), \mathrm{C}_{16: 0}(12.5 \%)$, and $\mathrm{C}_{18: 0}$ $(8.1 \%)$. A list of all detected fatty acids is provided in the species description. The molar $\mathrm{G}+\mathrm{C}$ content of strain $\mathrm{HN}$ $182^{\mathrm{T}}$ was determined to be $67.2 \mathrm{~mol} \%$ (by $T_{\mathrm{m}}$ ).

The almost complete $16 \mathrm{~S}$ rRNA gene (1428 nt) of strain $\mathrm{HN}-182^{\mathrm{T}}$ was amplified and sequenced. Database search by using BLAST on NCBI (Altschul et al., 1990) showed that strain $\mathrm{HN}-182^{\mathrm{T}}$ was related to P. versutus ATCC $25364^{\mathrm{T}}$ with the highest similarity of $96.7 \%$. Other closely related

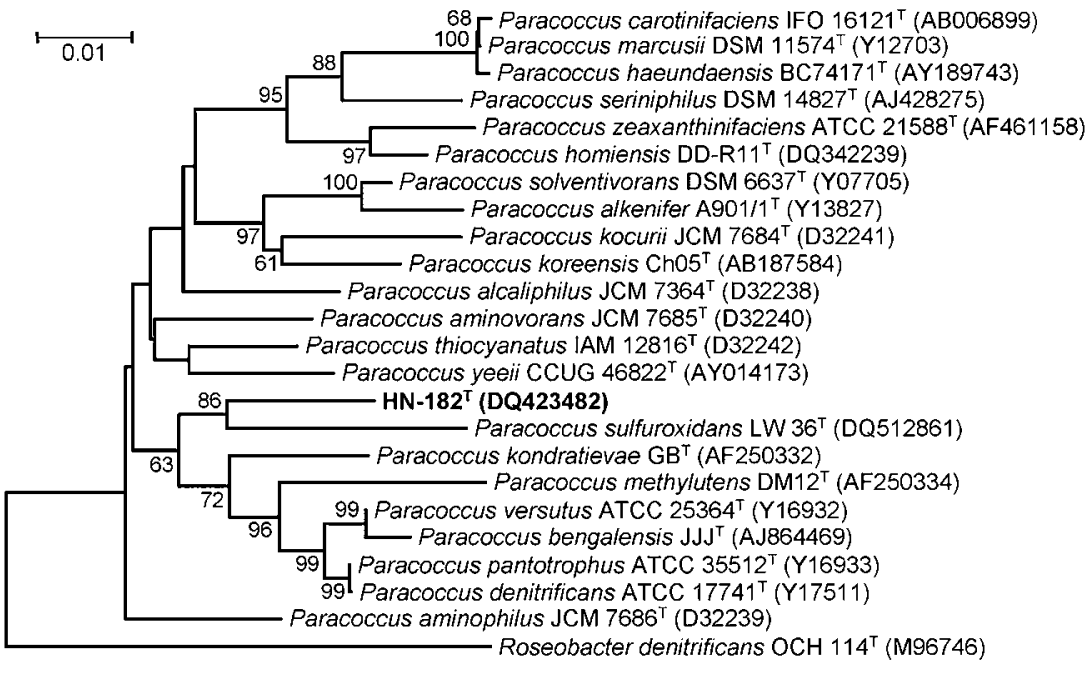

Fig. 1. Phylogenetic tree constructed with the neighbour-joining method based on 16S rRNA gene evolutionary distances among strain $\mathrm{HN}$ $182^{\top}$ and other Paracoccus species. Bootstrap values (expressed as percentages of 1000 replications) $>50 \%$ are shown at the branching points. Roseobacter denitrificans $\mathrm{OCH} 114^{\top}$ was used as outgroup. Bar, evolutionary distance $\left(\mathrm{K}_{\text {nuc }}\right)$ of 0.01 . 
Table 1. Differential properties of strain $\mathrm{HN}-182^{\top}$ and closely related Paracoccus species

Taxa: $1, \mathrm{HN}-182^{\mathrm{T}} ; 2$, P. sulfuroxidans (data from Liu et al., 2006); 3, P. versutus (Katayama et al., 1995); 4, P. denitrificans (Doronina et al., 1998; Rainey et al., 1999; Kelly et al., 2006a, b); 5, P. pantotrophus (Robertson \& Kuenen, 1983; Rainey et al., 1999); 6, P. kondratievae (Doronina et al., 2002); 7, P. bengalensis (Ghosh et al., 2006). +, Positive or present; -, negative or absent; NA, no data available.

\begin{tabular}{|lccccccc|}
\hline Characteristic & $\mathbf{1}$ & $\mathbf{2}$ & $\mathbf{3}$ & $\mathbf{4}$ & $\mathbf{5}$ & $\mathbf{6}$ & $\mathbf{7}$ \\
\hline Utilization of: & & & & & & & \\
L-Arabinose & + & + & + & + & - & + & + \\
D-Galactose & + & - & + & + & - & + & + \\
Maltose & + & + & + & + & NA & - & + \\
D-Mannose & + & - & + & + & + & - & - \\
D-Fructose & + & - & + & + & - & + & + \\
Lactose & - & - & - & - & - & - & + \\
Inositol & - & - & NA & + & NA & + & - \\
Sucrose & - & - & + & + & + & - & + \\
D-Xylose & + & - & + & + & NA & - & - \\
Sulfur compounds used for energy & & & & \\
Sulfide & - & + & + & + & + & - & + \\
Thiosulfate & - & + & + & + & + & + & + \\
Nitrate to N & - & - & + & + & + & + & + \\
Growth at/in: & & & & & & & \\
$7{ }^{\circ} \mathrm{C}$ & + & - & - & - & - & - & - \\
$45{ }^{\circ} \mathrm{C}$ & - & - & - & - & - & + & - \\
$8 \%$ NaCl & + & - & - & - & - & - & - \\
DNA G $+\mathrm{C}$ & 67.2 & 61.3 & 66.8 & 66.5 & $64-68$ & 62.5 & 65.3 \\
content (mol\%) & & & & & & & \\
& & & & & & & \\
\hline
\end{tabular}

species are Paracoccus bengalensis ( $96.5 \%$, Ghosh et al., 2006), Paracoccus pantotrophus (96.2\%) and Paracoccus sulfuroxidans $(95.8 \%)$. Phylogenetic trees were constructed with maximum-parsimony, maximum-likelihood and neighbour-joining methods. These methods generated a slightly different topology of the tree, but strain $\mathrm{HN}-182^{\mathrm{T}}$ and seven other species, including $P$. sulfuroxidans, generated a coherent cluster for all three trees. A neighbour-joining tree is shown in Fig. 1. It is interesting that strain $\mathrm{HN}-182^{\mathrm{T}}$ had the highest $16 \mathrm{~S}$ rRNA gene identity to that of $P$. versutus, but showed a closer relationship with $P$. sulfuroxidans in the phylogenetic trees. A possible explanation to this might be that the two sequences of strain $\mathrm{HN}-182^{\mathrm{T}}$ and $P$. sulfuroxidans showed a discontinuity in the sequence alignment corresponding to nucleotides $935-979$ of the $\mathrm{HN}-182^{\mathrm{T}}$ sequence.

Combining the above phenotypic and genotypic characteristics, it is concluded that strain $\mathrm{HN}-182^{\mathrm{T}}$ represents a novel species of the genus Paracoccus, for which the name Paracoccus halophilus sp. nov. is proposed.

\section{Emended description of genus Paracoccus Davis 1969}

The formal descriptions and emendations given by Davis et al. (1969), Katayama et al. (1995) and Ludwig et al.
(1993) remain correct. Some species of the genus Paracoccus are halophilic and halotolerant.

\section{Description of Paracoccus halophilus sp. nov.}

Paracoccus halophilus (ha.lo.phi'lus. Gr. n. hals, halos salt; Gr. adj. philos loving; N.L. masc. adj. halophilus salt-loving).

Cells are Gram-negative, aerobic, non-motile, non-sporeforming, coccoid to short rods, $0.4-0.5 \times 0.7-1.1 \mu \mathrm{m}$ in size. Colonies grown on MA for 2 days are $2 \mathrm{~mm}$ in diameter, smooth, circular, non-glossy, creamy white and convex. Growth occurs at temperatures of $7-42{ }^{\circ} \mathrm{C}$ and optimally at $25{ }^{\circ} \mathrm{C}$, but not at 4 or $45^{\circ} \mathrm{C}$. Cells grow at pH 5.0-9.0 and optimally at 7.0, but not at pH 4.5 or 9.5. $\mathrm{NaCl}$ is required for growth $[0.5-8.5 \%(\mathrm{w} / \mathrm{v})]$, with an optimum of $4.5 \%$. Positive for catalase, oxidase and urease activities. Negative for amylase and lipase activities. Agar, casein, starch, gelatin and Tweens are not hydrolysed. Utilizes glycerol, L-arabinose, cellobiose, D-fructose, Dgalactose, glucose, maltose, D-mannose, L-rhamnose, Dribose, mannitol, D-sorbitol and D-xylose. Does not utilize adonitol, ethanol, inositol, lactose, melibiose, melezitose, raffinose, sucrose or trehalose. Acid is produced from glucose. Nitrate is not reduced to nitrogen. Reduced sulfur does not support autotrophic growth. The sole respiratory ubiquinone of strain $\mathrm{HN}-182^{\mathrm{T}}$ is Q-10. The polar lipids are phosphatidylglycerol (PG), diphosphatidylglycerol (DPG), phosphatidylcholine (PC), an unidentified glycolipid (GL1) and an unidentified phospholipid (PL1). The cellular fatty acids (listed according to percentage) are $\mathrm{C}_{18: 1} \omega 7 c(60.7 \%), \mathrm{C}_{16: 0} \quad(12.5 \%), \mathrm{C}_{18: 0}$ (8.1\%), 11 methyl $\mathrm{C}_{18: 1} \omega 7 c(3.5 \%), \mathrm{C}_{17: 0}(3.0 \%), \mathrm{C}_{10: 0} 3-\mathrm{OH}$ $(1.8 \%), \mathrm{C}_{14: 0}(2.2 \%), \mathrm{C}_{18: 1} \omega 9 c(1.3 \%)$, iso- $\mathrm{C}_{15: 1} \mathrm{I}$ $(1.1 \%), \mathrm{C}_{17: 1} \omega 8 c(1.0 \%)$ and $\mathrm{C}_{14: 0} 3-\mathrm{OH}(0.8 \%)$. The following fatty acids were not detected: $\mathrm{C}_{12: 1} \omega 7 c, \mathrm{C}_{16: 1} \omega 7 c$ and $\mathrm{C}_{19: 0}$ cyclo. The $\mathrm{G}+\mathrm{C}$ content is $67.2 \mathrm{~mol} \%\left(T_{\mathrm{m}}\right)$.

The type strain, $\mathrm{HN}-182^{\mathrm{T}} \quad\left(=\mathrm{CGMCC} 1.6117^{\mathrm{T}}=\mathrm{JCM}\right.$ $\left.14014^{\mathrm{T}}\right)$, was isolated from a marine sediment from the South China Sea, China.

\section{Acknowledgements}

This work was supported by grants from National Natural Science Foundation of China and Chinese Academy of Sciences. We gratefully acknowledge Dr J. P. Euzéby at Laboratoire de Bactériologie, École Nationale Vétérinaire, Toulouse, France, and Professor H.-G. Trüper at the University of Bonn, Germany, for their constant help with the Latin language.

\section{References}

Allen, M. B. (1959). Studies with Cyanidium caldarium, an anomalously pigmented chlorophyte. Arch Mikrobiol 32, 270-277.

Altschul, S. F., Gish, W., Miller, W., Myers, E. W. \& Lipman, D. J. (1990). Basic local alignment search tool. J Mol Biol 215, 403-410.

Berry, A., Janssens, D., Hümbelin, M., Jore, J. P. M., Hoste, B., Cleenwerck, I., Vancanneyt, M., Bretzel, W., Mayer, A. F. \& other 
authors (2003). Paracoccus zeaxanthinifaciens sp. nov., a zeaxanthinproducing bacterium. Int J Syst Evol Microbiol 53, 231-238.

Collins, M. D. (1985). Isoprenoid quinone analysis in classification and identification. In Chemical Methods in Bacterial Systematics, pp. 267-287. Edited by M. Goodfellow \& D. E. Minnikin. London: Academic Press.

Davis, D. H., Doudoroff, M., Stanier, R. Y. \& Mandel, M. (1969). Proposal to reject the genus Hydrogenomonas: taxonomic implications. Int J Syst Bacteriol 19, 375-390.

Denner, E. B. M., Kolari, M., Hoornstra, D., Tsitko, I., Kämpfer, P., Busse, H.-J. \& Salkinoja-Salonen, M. (2006). Rubellimicrobium thermophilum gen. nov., sp. nov., a red-pigmented, moderately thermophilic bacterium isolated from coloured slime deposits in paper machines. Int J Syst Evol Microbiol 56, 1355-1362.

Dong, X.-Z. \& Cai, M.-Y. (2001). Determinative Manual for Routine Bacteriology. Beijing: Scientific Press (English translation).

Doronina, N. V., Trotsenko, Y. A., Krausova, V. I. \& Suzina, N. E. (1998). Paracoccus methylutens sp. nov. - a new aerobic facultatively methylotrophic bacterium utilizing dichloromethane. Syst Appl Microbiol 21, 230-236.

Doronina, N. V., Trotsenko, Y. A., Kuznetzov, B. B. \& Tourova, T. P. (2002). Emended description of Paracoccus kondratievae. Int J Syst Evol Microbiol 52, 679-682.

Fujii, K., Satomi, M., Morita, N., Motomura, T., Tanaka, T. \& Kikuchi, S. (2003). Novosphingobium tardaugens sp. nov., an oestradiol-degrading bacterium isolated from activated sludge of a sewage treatment plant in Tokyo. Int J Syst Evol Microbiol 53, 47-52.

Gerhardt, P., Murray, R. G. E., Wood, W. A. \& Krieg, N. R. (editors) (1994). Methods for general and molecular bacteriology. Washington, D. C.: American Society for Microbiology.

Ghosh, W., Mandal, S. \& Roy, P. (2006). Paracoccus bengalensis sp. nov., a novel sulfur-oxidizing chemolithoautotroph from the rhizosphere soil of an Indian tropical leguminous plant. Syst Appl Microbiol 29, 396-403.

Hu, Y.-T., Zhou, P.-J., Zhou, Y.-G., Liu, Z.-H. \& Liu, S.-J. (2004). Saccharothrix xingjiangensis, sp. nov., a pyrene-degrading actinomycete isolated from Tianchi lake, Xinjiang, China. Int J Syst Evol Microbiol 54, 2091-2094.

Hugh, R. \& Leifson, E. (1953). The taxonomic significance of fermentative versus oxidative metabolism of carbohydrates by various Gram-negative bacteria. J Bacteriol 66, 24-26.

Katayama, Y., Hiraishi, A. \& Kuraishi, H. (1995). Paracoccus thiocyanatus sp. nov., a new species of thiocyanate-utilizing facultative chemolithotroph, and transfer of Thiobacillus versutus to the genus Paracoccus as Paracoccus versutus comb. nov. with emendation of the genus. Microbiology 141, 1469-1477.

Kelly, D. P., Euzéby, J. P., Goodhew, C. F. \& Wood, A. P. (2006a). Redefining Paracoccus denitrificans and Paracoccus pantotrophus and the case for a reassessment of the strains held by international culture collections. Int J Syst Evol Microbiol 56, 2495-2500.

Kelly, D. P., Rainey, F. A. \& Wood, A. P. (2006b). The genus Paracoccus. In The Prokaryotes, A Handbook on the Biology of Bacteria, 3rd edn, vol. 5, pp. 232-249. Edited by M. Dworkin, S. Falkow, E. Rosenberg, K. H. Schleifer \& E. Stackebrandt. New York: Springer.

Kim, B.-Y., Weon, H.-Y., Yoo, S.-H., Kwon, S.-W., Cho, Y.-H., Stackebrandt, E. \& Go, S.-J. (2006). Paracoccus homiensis sp. nov., isolated from a sea-sand sample. Int J Syst Evol Microbiol 56, 2387-2390.

Kumar, S., Tamura, K. \& Nei, M. (2004). MEGA3: integrated software for molecular evolutionary genetics analysis and sequence alignment. Brief Bioinform 5, 150-163.
La, H. J., Im, W.-T., Ten, L. N., Kang, M. S., Shin, D. Y. \& Lee, S. T. (2005). Paracoccus koreensis sp. nov., isolated from anaerobic granules in an upflow anaerobic sludge blanket (UASB) reactor. Int J Syst Evol Microbiol 55, 1657-1660.

Labrenz, M., Collins, M. D., Lawson, P. A., Tindall, B. J., Braker, G. \& Hirsch, P. (1998). Antarctobacter heliothermus gen. nov., sp. nov., a budding bacterium from hypersaline and heliothermal Ekho Lake. Int J Syst Bacteriol 48, 1363-1372.

Labrenz, M., Collins, M. D., Lawson, P. A., Tindall, B. J., Schumann, P. \& Hirsch, P. (1999). Roseovarius tolerans gen. nov., sp. nov., a budding bacterium with variable bacteriochlorophyll a production from hypersaline Ekho Lake. Int J Syst Bacteriol 49, 137-147.

Labrenz, M., Lawson, P. A., Tindall, B. J., Collins, M. D. \& Hirsch, P. (2005). Roseisalinus antarcticus gen. nov., sp. nov., a novel aerobic bacteriochlorophyll $a$-producing $\alpha$-proteobacterium isolated from hypersaline Ekho Lake, Antarctica. Int J Syst Evol Microbiol 55, 41-47.

Lee, J. H., Kim, Y. S., Choi, T.-J., Lee, W. J. \& Kim, Y. T. (2004). Paracoccus haeundaensis sp. nov., a Gram-negative, halophilic, astaxanthinproducing bacterium. Int J Syst Evol Microbiol 54, 1699-1702.

Lipski, A., Reichert, K., Reuter, B., Sproer, C. \& Altendorf, K. (1998). Identification of bacterial isolates from biofilters as Paracoccus alkenifer sp. nov. and Paracoccus solventivorans with emended description of Paracoccus solventivorans. Int J Syst Bacteriol 48, 529-536.

Liu, X.-Y., Wang, B.-J., Jiang, C.-Y. \& Liu, S.-J. (2006). Paracoccus sulfuroxidans sp. nov., a sulfur oxidizer from activated sludge. Int $J$ Syst Evol Microbiol 56, 2693-2695.

Ludwig, W., Mittenhuber, G. \& Friedrich, C. G. (1993). Transfer of Thiosphaera pantotropha to Paracoccus denitrificans. Int J Syst Bacteriol 43, 363-367.

Macián, M. C., Arahal, D. R., Garay, E., Ludwig, W., Schleifer, K. H. \& Pujalte, M. J. (2005). Thalassobacter stenotrophicus gen. nov., sp. nov., a novel marine $\alpha$-proteobacterium isolated from Mediterranean sea water. Int J Syst Evol Microbiol 55, 105-110.

Marmur, J. \& Doty, P. (1962). Determination of the base composition of deoxyribonucleic acid from its thermal denaturation temperature. J Mol Biol 5, 109-118.

Pukall, R., Laroche, M., Kroppenstedt, R. M., Schumann, P., Stackebrandt, E. \& Ulber, R. (2003). Paracoccus seriniphilus sp. nov., an L-serine-dehydratase-producing coccus isolated from the marine bryozoan Bugula plumosa. Int J Syst Evol Microbiol 53, 443-447.

Rainey, F. A., Kelly, D. P., Stackebrandt, E., Burghardt, J., Hiraishi, A., Katayama, Y. \& Wood, A. P. (1999). A re-evaluation of the taxonomy of Paracoccus denitrificans and a proposal for the combination Paracoccus pantotrophus comb. nov. Int J Syst Bacteriol 49, 645-651.

Robertson, L. A. \& Kuenen, J. G. (1983). Thiosphaera pantotropha gen. nov. sp. nov., a facultatively anaerobic, facultatively, autotrophic sulphur bacterium. J Gen Microbiol 129, 2847-2855.

Siller, H., Rainey, F. A., Stackebrandt, E. \& Winter, J. (1996). Isolation and characterization of a new Gram-negative, acetone-degrading, nitrate-reducing bacterium from soil, Paracoccus solventivorans sp. nov. Int J Syst Bacteriol 46, 1125-1130.

Thompson, J. D., Gibson, T. J., Plewniak, F., Jeanmougin, F. \& Higgins, D. G. (1997). The CLUSTAL_X windows interface: flexible strategies for multiple sequence alignment aided by quality analysis tools. Nucleic Acids Res 25, 4876-4882.

Tsubokura, A., Yoneda, H. \& Mizuta, H. (1999). Paracoccus carotinifaciens sp. nov., a new aerobic Gram-negative astaxanthinproducing bacterium. Int J Syst Bacteriol 49, 277-282.

Ventosa, A., Marquez, M. C., Kocur, M. \& Tindall, B. J. (1993). Comparative study of "Micrococcus sp." strains CCM 168 and CCM 1405 and members of the genus Salinicoccus. Int J Syst Bacteriol 43, 245-248. 
Wu, C., Lu, X., Qin, M., Wang, Y. \& Ruan, J. (1989). Analysis of menaquinone compound in microbial cells by HPLC. Microbiology [English translation of Microbiology (Beijing)] 16, 176-178.
Zhang, D., Yang, H., Zhang, W., Huang, Z. \& Liu, S.-J. (2003). Rhodocista pekingensis sp. nov., a cyst-forming phototrophic bacterium from a municipal wastewater treatment plant. Int J Syst Evol Microbiol 53, 1111-1114. 